\title{
Improving the yield and fruiting characteristics of Ewais Mango Cultivar by spraying with Nano-chitosan and Nano-potassium silicate
}

\author{
M.M. Gad', M.A. Abdel-Mohsen², O.A. Zagzog $^{3}$ \\ ${ }^{1}$ Pomology Department, Faculty of Agriculture, Zagazig University, Sharkia, Egypt \\ ${ }^{2}$ Pomology Department, Faculty of Agriculture, Cairo University, Giza, Egypt \\ ${ }^{3}$ Department of Plant Production, Faculty of Technology and Development, Zagazig University, \\ Zagazig, Egypt
}

Received on: 24-10-2021

Accepted on: 27-11-2021

\begin{abstract}
This study was carried to improve flowering, productivity and fruit quality of the Ewais mango cultivar by foliar spraying with Nano-chitosan and Nano-potassium silicate. This trial included seven treatments, before flowering selected trees were sprayed with Nano- chitosan at 50, 100 or $150 \mathrm{ppm}$, Nano-potassium silicate at $0.4,0.6,0.8 \mathrm{~g} / \mathrm{L}$ and control treatment. Under this experiment conditions, the Ewais mango cultivar showed a positive response to the treatments with Nanoparticles, whether for chitosan or potassium silicate, compared to the untreated trees, which gave the lowest results in the characteristics related to flowering, fruit set, yield, fruiting characteristics and the leaves content of chlorophyll, zinc, and potassium. Spraying Nano-potassium silicate at 0.6 and $0.8 \mathrm{~g} / \mathrm{L}$ were more effective in increasing panicle length and decreasing floral malformation in addition to achieving the highest yield and the best fruit characteristics as compared with un-treated trees. Also, Nano- potassium silicate at $0.8 \mathrm{~g} / \mathrm{L}$ was more effective in enhancing final fruit set than other treatments. Furthermore, spraying the trees with chitosan at a concentration of 50 or $100 \mathrm{ppm}$ showed the nearest or same results as those achieved with Nano- potassium silicate. Application with Nanoparticles of chitosan at a concentration of 50 or $100 \mathrm{ppm}$ lead to improve leaves content of chlorophyll, zinc, and potassium.

It is recommended spraying Ewais mango with Nano-potassium silicate at $0.6 \mathrm{~g} / \mathrm{L}$ or Nano chitosan at 100 ppm which decreased floral malformation and achieved the highest yield \& the best fruit characteristics.
\end{abstract}

KEYWORDS: Mango, Ewais cultivar, Nanoparticles, Nano-chitosan, Nano-potassium silicate, yield, fruit quality, chlorophyll, leaf $\mathrm{K}$ and $\mathrm{Zn}$ content.

\section{INTRODUCTION}

Mango consider the most favorable fruit in Egypt. It has been cultivated since the $19^{\text {th }}$ century until now, there are at least 40 cultivars which are propagated and grown in commercial scale (EMALR, 2004). Great differences have been detected among these cultivars in vegetative and reproductive characters, production, yield and fruit characters (Elsheshetawy et al., 2016). The Ewais cultivar is considered one of the most important Egyptian mango varieties (Riad, 1997). It is characterized by its high content of sugars and excellent flavor, but it is malicious for its low yield.

Agrochemicals application faces problems of over-application and reduced bioavailability due to soil chelation and runoff. Therefore, there is a need to focus on the improving efficacy (Kashyap et al., 2015). From here the potential of nanomaterials has received increased attention to improve current agriculture practices by enhancement of crop production and disease management (Thornton, 2010).
In agriculture, nanomaterial offer potential problemsolving applications by regulated release of encapsulated fertilizers, micronutrients, pesticides and detection of plant diseases, pollutants, pests and pathogens (Ghormade et al., 2011). The potential application of nano particle materials in plant growth and protection is developing effective and potential approaches to increase crop growth and controlling plant pathogens. The application of nanomaterials in plants is largely related to altering gene expression and different biological pathways which affects plant growth and development (Nair et al., 2010).

Among them, chitosan-based nanomaterials and nanocomposites, have attracted great interest in agriculture due to their antimicrobial, plant growth enhancement, immune enhancement, and disease control properties (Kumaraswamy et al., 2018). Chitosan based nanomaterials have excellent physicochemical characters due to their small size, high ratio of surface-to-volume and surface charge compared to chitosan. Chitosan is a non-toxic, biodegradable linear 


\section{M.M. Gad et al., 2021}

copolymer composed of 2-acetamido-2-deoxy-beta-dglucopyranose and 2-amino-2-deoxy-beta-dglucopyranose. It is produced from chitin by deacetylation using alkaline hydrolysis or enzymatic treatment (Choudhary et al., 2017a). The unique properties of chitosan, such as biocompatibility, biodegradability, hydrophilicity, safe, and non-toxic nature, chitosan-based nanomaterials are used in many agricultural (Saharan et al., 2013, 2015), plant growth promotion activity (Saharan et al., 2015, 2016, Choudhary et al., 2017b) and nano-fertilizers (AbdelAziz et al. 2016). The engineered nanomaterials of chitosan are natural materials with different physicochemical properties than normal one; Moreover, it is biologically active and ecofriendly (Agnihotri et al., 2004). Foliar spraying with low concentration $10 \%$ of chitosan nanoparticles showed improvement in the growth and productivity of wheat plants (Abdel-Aziz et al., 2016). The nanoparticles of chitosan absorbed easily by the leaves epidermis then transferred to the stems facilitating the absorption of the active molecules and enhancing the growth process and productivity of many crops and other plants (Malerba and Cerana, 2016).

Potassium silicate used in agriculture as a fertilizer as well as additional nutrients for wide range of plants (Kikuchi, 1999; Yao et al., 2003; Wu and Liu, 2007). It is used as the main source of silicon for its role in plants as well as containing potassium. The use of potassium silicate as a nutrient is a possibility to increase the sugars and amino acids concentrations in plants. Thus, the plants are resistant to insects and diseases, also increased different quality characteristics as taste, size and color (Kikuchi, 1999). Using nanoform of potassium silicate may be improve its properties, as it can introduce different biological activities with variable chemical-physical properties such as surface area, volume, positive nature, etc. Nanoparticles exhibit different properties from bulk materials (Roduner 2006).

In this context, silicon ( $\mathrm{Si})$, which is considered beneficial to plants, is able to alleviate some of the stress that affects them, thus preserving its productive potential (Ma JF, 2004 and Savvas and Ntatsi, 2015). Si is an essential element for plants, it enhances the tolerance ability of plants to different environmental stress conditions (Luyckx et al., 2017). Likewise, silicon nanoparticles have been observed to exhibit different physical and chemical properties from bulk materials (O'Farrell et al., 2006). The properties of silicon nanoparticles allow it to enter plants and influence different metabolic activities of the plant. Silicon nanoparticles which has a porous nature also makes them good candidates as nanoparticles suitable for different molecules that may aid in cultivation (Rastogi et al., 2019).

As well as the usage of potassium silicates, this may be due to their potassium content. This is a common plant macronutrient that is provided by fertilizers. It acts as a stimulant of more than 60 different enzymatic reactions, aids in the synthesis of ATP, and maintains overall plant well-being by controlling the oral activities of plants to regulate water and gas exchange (Nido et al., 2019). The use of nano-fertilizers not only increases the efficiency of the use of the elements but also reduces the toxicity resulting from excessive use in the soil as well as reduces the cleavage application of the fertilizers (Naderi and Danesh-Shahraki, 2013).

This research aims to improve the flowering, productivity and fruit quality of the Ewais mango cultivar by foliar spraying with Nano- chitosan and Nano- potassium silicate.

\section{MATERIALS AND METHODS}

This study was conducted during the 2019 and 2020 seasons on Ewais mango cultivar grown in a private orchard in Wadi Al-Molak, Sharkia Governorate, Egypt. Twenty years old trees were grown in sandy soil under a drip irrigation system, planted 4 x 6 meters away, and grafted on Succary rootstocks. Twenty-one healthy trees of similar strength and size were selected to assess the effect of foliar spraying with Nano-chitosan and Nanopotassium silicate on flowering, fruiting and fruit quality of the Ewais mango cultivar.

Chitosan and potassium silicate nanoparticles were from Nano-crystalline powder made by high-power ball milling as described by Gad and Ibrahim, 2018. Powder mixture was performed by prof. Dr. Osama M. Hemeda at faculty of science, Tanta University, Egypt. The microstructure of the examined sintered samples was examined with a High Resolution Transmission Electron Microscope model (HRTEM) JOEL EM 2-100 as showed in Fig. 1 and Fig 2 which showed the morphological characteristics and surface appearance of the Nanochitosan and Nano-potassium silicate particles, which have a nearly smooth surface, spherical shape and a size range of about $35-50 \mathrm{~nm}$, confirming the result from 
Scientific Journal of Agricultural Sciences 3 (2): 68-77, 2021

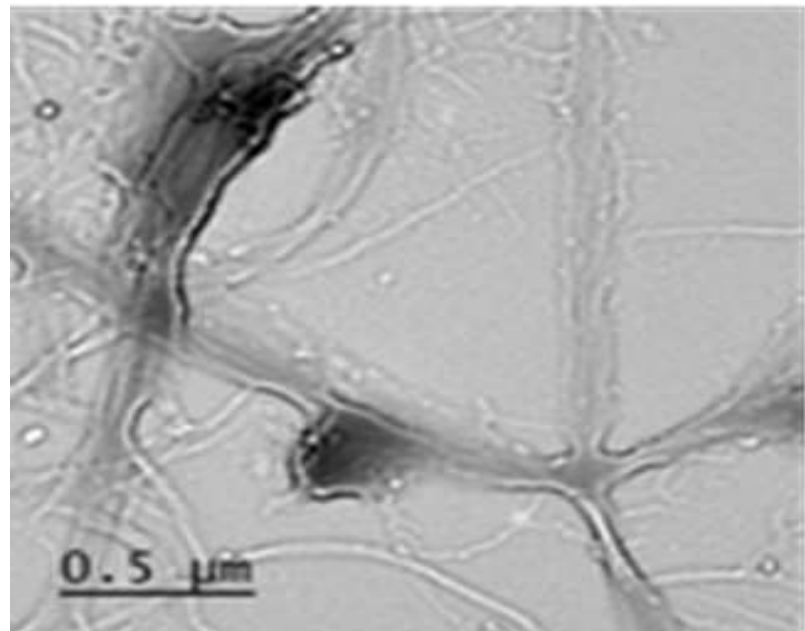

(a)

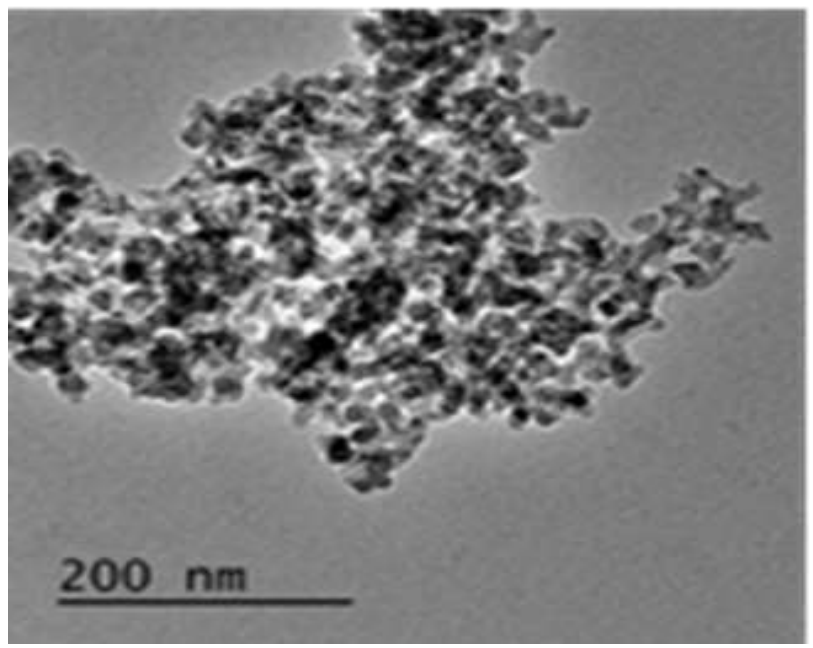

(b)

Fig.1. (a-b): Chitosan TEM micrograph, before milling (a) and after milling (b)

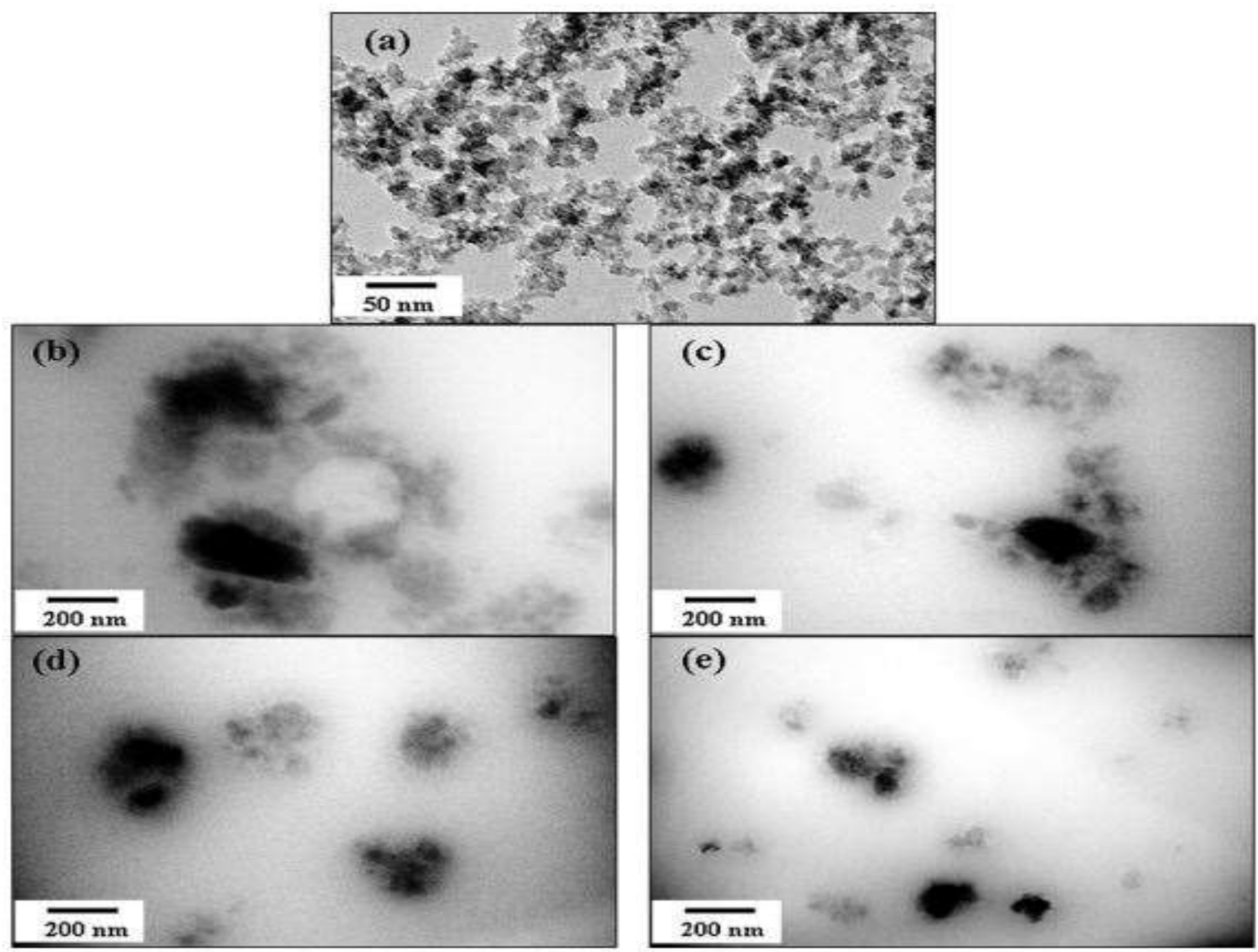

Fig 2. (a-b-c-d-e): TEM micrograph for potassium silicate particles, (a) after milling at $50 \mathrm{~nm}$ resolution and (b-c-d-e) after milling at $200 \mathrm{~nm}$ resolution

XRD. The sizes of chitosan and potassium silicate nanoparticles as indicated by the TEM images found are
$50 \mathrm{~nm}$. The chitosan nanoparticles TEM analysis showed a uniform size distribution in the nanometer scale. 


\section{M.M. Gad et al., 2021}

\subsection{Dissolving chitosan:}

The stock solution of chitosan $(2.0 \% \mathrm{w} / \mathrm{v})$ was prepared as described by (Du et al., 1997) then the sterile distilled water used to obtain the appropriate concentrations.

This trial included seven treatments, each treatment repeated three times with one tree for each replicate. Selected trees were spraying with Nano chitosan at a rate of 50,100 or $150 \mathrm{ppm}$, or with Nano - potassium silicate at a rate of $00.4,0.6$ and $0.8 \mathrm{~g} / \mathrm{L}$, in addition to spraying with tap water (control). Trees were sprayed prior to flowering on February 15.

\subsection{Measurements:}

Thirty terminal shoots per tree ( 90 shoots per treatment) were tagged on February 15 to record the following parameters.

Panicle length $(\mathrm{cm})$, floral malformation $(\%)$, initial fruit set (setting fruits number per panicle after two weeks of petal fall), final fruit set (number of retained fruits per panicle at harvest) and fruit retention (\%) at harvest by the following equation: Final fruit set/ Initial fruit set $\times 100$.

Also, number of fruits per tree was counted at harvest time (first week of August in both seasons) then yield ( $\mathrm{kg} /$ tree) was estimated by multiplying number of fruits per tree $\times$ the average of fruit weight $(\mathrm{g})$. Production (ton/fed.) was calculated by multiplying yield $\mathrm{kg}$ per tree $\times$ number of trees per feddan (175 trees). Samples of five firm ripe (commercial stage) fruits were taken from each replicate for determining fruit weight (g), fruit total soluble solids (TSS\%) and fruit acidity (\%) using the titration method against $\mathrm{NaOH}(0.1 \mathrm{~N})$ in the presence of phenol phethalein, as an indicator, according to A.O.A.C. (1990) to calculate citric acid. Also, TSS acid ratio was calculated.

In addition, a leaf sample (10 leaves) was selected from each tree (fourth and fifth leaves from the new growth base) for determining total chlorophyll according to Wettestein (1957). Also, K concentrations were determined using a flame photometer (CORNING M 410) (Chapman and Pratt, 1961). Zinc was determined using a "Pye Unicam Model SP-1900" atomic absorption spectrophotometer with boiling air - acetylene.

\subsection{Statistical analysis:}

This experiment was arranged in a Completely Randomized Block Design with three replicates per treatment and the data were subjected to variance analysis according to (Steel and Torrie, 1980) using MSTAT software. Significant averages between treatments were compared using Duncan (1955) with a $5 \%$ probability according to Snedecor and Cochran (1980).

\section{RESULTS}

The results in Table (1) explained that all concentrations of Nano-potassium silicate significantly improved panicle length compared to the control and Nano-chitosan in two seasons. Moreover, the tallest panicle was detected with Nano-potassium silicate at 0.6 and $0.8 \mathrm{~g} / \mathrm{L}$ for first and second seasons respectively. Meanwhile the shortest panicles were recorded with the control in both seasons.

Concerning floral malformation percentages the lowest values were observed with Nanopotassium silicate at $0.4 \mathrm{~g} / \mathrm{L}$ followed by Nanopotassium silicate at $0.8 \mathrm{~g} / \mathrm{L}$. On the other hand the highest floral malformation percentage was found with the control. In general, the effect of spraying of Nano-potassium silicate treatments were more effective in increasing panicle length and decreasing floral malformation as compared with un-treated tree or that treated by Nano-chitosan in the $1^{\text {st }}$ and $2^{\text {nd }}$ seasons. This had a good effect later on the quantity of the crop.

Regarding initial fruit set (Table, 2), the highest significant values were recorded with Nanopotassium silicate $0.8 \mathrm{~g} / \mathrm{L}$ in both seasons followed by Nano-chitosan $100 \mathrm{ppm}$ in the first season and Nano-potassium silicate $0.6 \mathrm{~g} / \mathrm{L}$ in the second one. On the contrary, the control trees produced the lowest initial fruit set in both seasons.

As for final fruit set data in Table (2) indicted that Nano-potassium silicate at $0.8 \mathrm{~g} / \mathrm{L}$ was more effective in enhancing final fruit set than other treatments where it recorded the highest significant values in both seasons. On the contrary, the untreated trees produced the lowest values of final fruit set. The other tested treatments came in between. 
Scientific Journal of Agricultural Sciences 3 (2): 68-77, 2021

Table 1. Panicle length $(\mathrm{cm})$ and floral malformation \% of Ewais mango cultivar as influenced by foliar spraying with Nano-chitosan and Nano-potassium silicate before flowering during 2019 and 2020 seasons.

\begin{tabular}{|c|c|c|c|c|c|c|c|c|}
\hline \multirow{2}{*}{ Treatments } & \multicolumn{3}{|c|}{ Panicle length $(\mathrm{cm})$} & \multicolumn{5}{|c|}{ Floral Malformation \% } \\
\hline & 2019 & & 2020 & & 2019 & & 2020 & \\
\hline Control & 25.00 & d & 28.10 & $\mathrm{e}$ & 45.00 & $\mathrm{a}$ & 40.60 & $\mathrm{a}$ \\
\hline Nano-chitosan 50 ppm & 40.00 & $\mathrm{c}$ & 36.20 & $d$ & 27.30 & $\mathrm{~b}$ & 24.00 & $\mathrm{~b}$ \\
\hline Nano-chitosan 100 ppm & 50.00 & $\mathrm{~b}$ & 46.60 & $\mathrm{c}$ & 21.00 & $\mathrm{c}$ & 23.30 & $\mathrm{~b}$ \\
\hline Nano-chitosan 150 ppm & 43.30 & $\mathrm{c}$ & 39.00 & d & 26.60 & $\mathrm{~b}$ & 23.00 & $\mathrm{~b}$ \\
\hline Nano-K silicate $0.4 \mathrm{~g} / \mathrm{L}$ & 58.00 & $\mathrm{a}$ & 62.10 & $\mathrm{a}$ & 17.30 & $\mathrm{~d}$ & 16.60 & $\mathrm{cc}$ \\
\hline Nano-K silicate $0.6 \mathrm{~g} / \mathrm{L}$ & 62.30 & $\mathrm{a}$ & 58.30 & $\mathrm{~b}$ & 21.00 & $\mathrm{c}$ & 18.60 & $\mathrm{c}$ \\
\hline Nano-K silicate $0.8 \mathrm{~g} / \mathrm{L}$ & 60.60 & $\mathrm{a}$ & 62.70 & a & 16.30 & $\mathrm{~d}$ & 15.30 & $\mathrm{~d}$ \\
\hline
\end{tabular}

*Values within a column with similar letter (s) were not significantly different based on the least significant difference at $0.05 \%$.

Table 2. Initial and final fruit set of Ewais mango cultivar as influenced by foliar spraying with Nanochitosan and Nano-potassium silicate before flowering during 2019 and 2020 seasons.

\begin{tabular}{|c|c|c|c|c|c|c|c|c|}
\hline \multirow{2}{*}{ Treatments } & \multicolumn{3}{|c|}{ Initial fruit set } & \multicolumn{5}{|c|}{ Final fruit set } \\
\hline & 2019 & & 2020 & & 2019 & & 2020 & \\
\hline Control & 12.00 & $\mathrm{f}$ & 11.00 & $\mathrm{e}$ & 1.30 & $\mathrm{c}$ & 1.30 & $\mathrm{e}$ \\
\hline Nano-chitosan 50 ppm & 25.60 & $\mathrm{~b}$ & 20.00 & $\mathrm{c}$ & 2.30 & a & 1.60 & $\mathrm{~d}$ \\
\hline Nano-chitosan 100 ppm & 28.30 & $\mathrm{a}$ & 20.00 & $\mathrm{c}$ & 2.00 & $b$ & 2.60 & $\mathrm{~b}$ \\
\hline Nano-chitosan 150 ppm & 16.30 & $\mathrm{e}$ & 13.30 & $\mathrm{~d}$ & 2.30 & a & 1.00 & $\mathrm{f}$ \\
\hline Nano-K silicate $0.4 \mathrm{~g} / \mathrm{L}$ & 21.00 & $\mathrm{~d}$ & 23.00 & $\mathrm{~b}$ & 2.00 & $b$ & 2.00 & $\mathrm{c}$ \\
\hline Nano-K silicate $0.6 \mathrm{~g} / \mathrm{L}$ & 23.00 & $\mathrm{c}$ & 25.00 & $\mathrm{a}$ & 2.30 & $\mathrm{a}$ & 1.60 & $\mathrm{~d}$ \\
\hline Nano-K silicate $0.8 \mathrm{~g} / \mathrm{L}$ & 28.00 & $\mathrm{a}$ & 25.00 & $\mathrm{a}$ & 2.30 & $\mathrm{a}$ & 3.30 & $\mathrm{a}$ \\
\hline
\end{tabular}

*Values within a column with similar letter (s) were not significantly different based on the least significant difference at $0.05 \%$.

Concerning fruit retention as affected by different spraying treatments, (Table 3) indicated that, Nanochitosan $150 \mathrm{ppm}$ and Nano-potassium silicate $0.8 \mathrm{~g} / \mathrm{L}$ treatments gave significant increases in fruit retention comparing with Nano-chitosan at $100 \mathrm{ppm}$ and 50 ppm in the first and second seasons, respectively. The rest tested treatments came in between.
Treated trees with Nano -chitosan at $50 \mathrm{ppm}$ in the first season and $100 \mathrm{ppm}$ in the second one produced the highest significant fruit number per tree compared with untreated trees. Where, the lowest values were obtained with the control in both seasons.

Table 3. Fruit retention percentage and number of fruits/tree of Ewais mango cultivar as influenced by foliar spraying with Nano-chitosan and Nano-potassium silicate before flowering during 2019 and 2020 seasons.

\begin{tabular}{llllllllll}
\hline \multirow{2}{*}{ Treatments } & \multicolumn{3}{c}{ Fruit retention (\%) } & \multicolumn{5}{c}{ Number of fruits/tree } \\
\cline { 2 - 10 } & $\mathbf{2 0 1 9}$ & $\mathbf{2 0 2 0}$ & & $\mathbf{2 0 1 9}$ & $\mathbf{2 0 2 0}$ & \\
\hline Control & 10.80 & $\mathrm{~b}$ & 11.80 & $\mathrm{~b}$ & 27.00 & $\mathrm{~d}$ & 22.00 & $\mathrm{f}$ \\
Nano-chitosan 50 $\mathbf{~ p p m}$ & 8.90 & $\mathrm{de}$ & 8.00 & $\mathrm{~cd}$ & 75.67 & $\mathrm{a}$ & 69.33 & $\mathrm{c}$ \\
Nano-chitosan 100 $\mathbf{~ p p m}$ & 7.00 & $\mathrm{f}$ & 13.00 & $\mathrm{a}$ & 74.67 & $\mathrm{ab}$ & 79.00 & $\mathrm{a}$ \\
Nano-chitosan 150 $\mathbf{~ p p m}$ & 14.10 & $\mathrm{a}$ & 7.50 & $\mathrm{~d}$ & 71.33 & $\mathrm{~b}$ & 70.00 & $\mathrm{c}$ \\
Nano-K silicate 0.4 g/L & 9.50 & $\mathrm{~cd}$ & 8.60 & $\mathrm{c}$ & 74.00 & $\mathrm{ab}$ & 75.00 & $\mathrm{~b}$ \\
Nano-K silicate 0.6 g/L & 10.00 & $\mathrm{bc}$ & 6.40 & $\mathrm{e}$ & 73.00 & $\mathrm{ab}$ & 65.67 & $\mathrm{~d}$ \\
Nano-K silicate 0.8 g/L & 8.20 & $\mathrm{e}$ & 13.20 & $\mathrm{a}$ & 52.33 & $\mathrm{c}$ & 40.67 & $\mathrm{e}$ \\
\hline
\end{tabular}


In addition yield $\mathrm{kg}$ per tree Table (4) showed that, Nano-potassium silicate at $0.6 \mathrm{~g} / \mathrm{L}$ and $0.4 \mathrm{~g} / \mathrm{L}$ achieved the highest yield per tree in the two seasons respectively. Whereas the lowest yield per tree was recorded with the control treatment in both seasons. The rest treatments achieved intermediate values.
Significantly the highest production (Ton/fed.) was obtained with Nano-potassium silicate at $0.6 \mathrm{~g} / \mathrm{L}$ followed by nano-chitosan at $100 \mathrm{ppm}$ in the first season and with Nano-potassium silicate $0.4 \mathrm{~g} / \mathrm{L}$ followed by nano-chitosan $100 \mathrm{ppm}$ in the second one without differences significantly between them. While the lowest value was obtained with the untreated trees in both seasons.

Table 4. Yield (kg/tree), production (ton/fed) and fruit weight (g) of Ewais mango cultivar as influenced by foliar spraying with Nano-chitosan and Nano-potassium silicate before flowering during 2019 and 2020 seasons.

\begin{tabular}{|c|c|c|c|c|c|c|c|c|c|c|c|c|}
\hline \multirow{2}{*}{ Treatments } & \multicolumn{4}{|c|}{ Yield (Kg/tree) } & \multicolumn{4}{|c|}{ Production (Ton/Fed) } & \multicolumn{4}{|c|}{ Fruit weight (g) } \\
\hline & 2019 & & 2020 & & 2019 & & 2020 & & 2019 & & 2020 & \\
\hline Control & 4.80 & $\mathrm{e}$ & 3.50 & $\mathrm{e}$ & 0.84 & $\mathrm{e}$ & 0.61 & $\mathrm{e}$ & 178.0 & $\mathrm{e}$ & 161.0 & $\mathrm{D}$ \\
\hline Nano-chitosan 50 ppm & 16.90 & $\mathrm{~b}$ & 15.50 & $\mathrm{c}$ & 2.95 & $\mathrm{~b}$ & 2.71 & $\mathrm{c}$ & 223.0 & $d$ & 225.0 & $\mathrm{C}$ \\
\hline Nano-chitosan 100 ppm & 19.30 & $\mathrm{a}$ & 19.80 & $\mathrm{a}$ & 3.37 & a & 3.46 & $\mathrm{a}$ & 256.0 & $\mathrm{~b}$ & 251.0 & B \\
\hline Nano-chitosan 150 ppm & 15.80 & $\mathrm{c}$ & 17.50 & $\mathrm{~b}$ & 2.76 & $\mathrm{c}$ & 3.06 & $\mathrm{~b}$ & 221.0 & $\mathrm{~d}$ & 249.0 & $\mathrm{~B}$ \\
\hline Nano-K silicate 0.4 g/L & 17.70 & $\mathrm{~b}$ & 20.50 & $\mathrm{a}$ & 3.10 & $\mathrm{~b}$ & 3.60 & $\mathrm{a}$ & 235.0 & c & 273.0 & A \\
\hline Nano-K silicate $0.6 \mathrm{~g} / \mathrm{L}$ & 20.10 & $\mathrm{a}$ & 15.40 & $\mathrm{c}$ & 3.51 & a & 2.69 & $\mathrm{c}$ & 276.0 & a & 235.0 & $\mathrm{C}$ \\
\hline Nano-K silicate $0.8 \mathrm{~g} / \mathrm{L}$ & 13.70 & $\mathrm{~d}$ & 10.40 & $\mathrm{~d}$ & 2.39 & $\mathrm{~d}$ & 1.82 & $\mathrm{~d}$ & 262.0 & b & 257.0 & B \\
\hline
\end{tabular}

*Values within a column with similar letter (s) were not significantly different based on the least significant difference at $0.05 \%$.

Regarding the fruit weight, the same table show that the highest significant values were recorded for tree treated with Nano-potassium silicate $0.6 \mathrm{~g} / \mathrm{L}$ and $0.4 \mathrm{~g} / \mathrm{L}$ in both seasons while the lowest value was obtained with the untreated trees.

As for fruit TSS, results in Table (5) indicated that Nano-chitosan at $100 \& 150$ ppm and Nanopotassium silicate at 0.4 and $0.6 \mathrm{~g} / \mathrm{L}$ gave the highest values in the $1^{\text {st }}$ and $2^{\text {nd }}$ seasons, respectively. On the contrary, the lowest value was obtained with the control. The other tested treatments recorded intermediate values.
Concerning fruit acidity, Table (5), showed that, Nano - potassium silicate at 0.4 and $0.6 \mathrm{~g} / \mathrm{L}$ achieved the highest values in the $1^{\text {st }}$ and $2^{\text {nd }}$ seasons. Meanwhile, the lowest fruit acidity was detected with Nano-chitosan at $100 \mathrm{ppm}$.

Results in the same table showed that Nanochitosan at $100 \mathrm{ppm}$ treatment recorded significantly highest TSS/acid ratio in both seasons compared to all rest treatments. On the contrary, the lowest TSS/acid ratio was recorded by Nano-potassium silicate at 0.4 and $0.6 \mathrm{~g} / \mathrm{L}$ treatments, in the two seasons, respectively.

Table 5. Fruit TSS (\%), fruit acidity (\%) and TSS/ Acid ratio of Ewais mango cultivar as influenced by foliar spraying with Nano-chitosan and Nano-potassium silicate before flowering during 2019 and 2020 seasons.

\begin{tabular}{|c|c|c|c|c|c|c|c|c|c|c|c|c|}
\hline \multirow{2}{*}{ Treatments } & \multicolumn{4}{|c|}{ Fruit TSS (\%) } & \multicolumn{4}{|c|}{ Fruit acidity (\%) } & \multicolumn{3}{|c|}{ TSS/ Acid ratio } & \\
\hline & 2019 & & 2020 & & 2019 & & 2020 & & 2019 & & 2020 & \\
\hline Control & 10.00 & $\mathrm{c}$ & 9.50 & $\mathrm{~d}$ & 0.76 & $\mathrm{~b}$ & 0.50 & $\mathrm{~d}$ & 13.05 & $\mathrm{e}$ & 19.00 & $\mathrm{~b}$ \\
\hline Nano-chitosan 50 ppm & 12.00 & $a b$ & 11.67 & $a b$ & 0.56 & $\mathrm{~d}$ & 0.70 & b & 21.40 & $\mathrm{c}$ & 16.57 & $\mathrm{c}$ \\
\hline Nano-chitosan 100 ppm & 13.00 & $\mathrm{a}$ & 11.00 & bc & 0.46 & $\mathrm{e}$ & 0.50 & $\mathrm{~d}$ & 28.23 & $\mathrm{a}$ & 22.00 & $\mathrm{a}$ \\
\hline Nano-chitosan 150 ppm & 13.00 & $\mathrm{a}$ & 10.20 & $\mathrm{~cd}$ & 0.53 & de & 0.56 & $\mathrm{c}$ & 24.52 & $\mathrm{~b}$ & 20.00 & $\mathrm{~b}$ \\
\hline Nano-K silicate $0.4 \mathrm{~g} / \mathrm{L}$ & 11.50 & $\mathrm{~b}$ & 12.00 & $\mathrm{a}$ & 0.96 & $\mathrm{a}$ & 1.00 & a & 11.57 & $\mathrm{e}$ & 12.00 & $\mathrm{~d}$ \\
\hline Nano-K silicate $0.6 \mathrm{~g} / \mathrm{L}$ & 11.83 & $a b$ & 11.90 & $\mathrm{a}$ & 1.00 & $\mathrm{a}$ & 1.00 & $\mathrm{a}$ & 11.80 & $\mathrm{e}$ & 11.90 & $\mathrm{~d}$ \\
\hline Nano-K silicate $0.8 \mathrm{~g} / \mathrm{L}$ & 11.83 & $a b$ & 11.50 & $a b$ & 0.66 & $\mathrm{c}$ & 0.66 & $\mathrm{~b}$ & 17.87 & $\mathrm{~d}$ & 17.42 & $\mathrm{c}$ \\
\hline
\end{tabular}

*Values within a column with similar letter (s) were not significantly different based on the least significant difference at $0.05 \%$. 
Leaf total chlorophyll content as in Table (6) was significantly response to the studied treating trees. Untreated trees recorded the lowest significant values of total leaf chlorophyll in both seasons. The highest total leaf chlorophyll values was achieved with trees treated with Nano-chitosan at $100 \mathrm{ppm}$ in the first season and $50 \& 150 \mathrm{ppm}$ in the second season, followed by Nano - potassium silicate at $0.6 \mathrm{~g} / \mathrm{L}$ in the first season.

As for leaf potassium content (\%), results in Table (6) indicated that Nano-chitosan at $50 \& 100$ ppm and Nano-potassium silicate at $0.8 \mathrm{~g} / \mathrm{L}$ gave the highest values in the $1^{\text {st }}$ seasons while that achieved with Nano-chitosan at 100 ppm only and Nanopotassium silicate at $0.6 \& 0.8 \mathrm{~g} / \mathrm{L}$ in the $2^{\text {nd }}$ season. Contrary, the lowest value was obtained with the untreated trees.

Similar results were achieved with leaf zinc content (ppm). The results in same Table showed that untreated trees achieved the lowest significant values for the leaves zinc content in both seasons. Whereas the significantly highest values were achieved for trees treated with Nano-chitosan at 50 \& 100 ppm, followed by Nano-potassium silicate at all concentrations in the two seasons.

Table 6. Leaf total chlorophyll content (mg/ $100 \mathrm{mg} \mathrm{F.W.),} \mathrm{potassium} \mathrm{content} \mathrm{( \% )} \mathrm{and} \mathrm{zinc} \mathrm{content} \mathrm{(ppm)}$ of Ewais mango cultivar as influenced by foliar spraying with Nano-chitosan and Nanopotassium silicate before flowering during 2019 and 2020 seasons.

\begin{tabular}{|c|c|c|c|c|c|c|c|c|c|c|c|c|}
\hline \multirow[t]{2}{*}{ Treatments } & \multicolumn{4}{|c|}{$\begin{array}{c}\text { Leaf Total chlorophyll } \\
\text { content } \\
(\mathrm{mg} / \mathbf{1 0 0} \mathbf{g} \mathbf{F} . \mathbf{W} .)\end{array}$} & \multicolumn{4}{|c|}{$\begin{array}{l}\text { Leaf Potassium content } \\
\qquad(\%)\end{array}$} & \multicolumn{4}{|c|}{$\begin{array}{c}\text { Leaf Zinc } \\
\text { content (ppm) }\end{array}$} \\
\hline & 2019 & & 2020 & & 2019 & & 2020 & & 2019 & & 2020 & \\
\hline Control & 2.23 & $\mathrm{e}$ & 2.14 & $\bar{d}$ & 1.72 & $\mathrm{c}$ & 1.70 & $\bar{c}$ & 29.38 & $\mathrm{~d}$ & 2.66 & $\mathrm{~d}$ \\
\hline Nano-chitosan 50 ppm & 3.54 & $\mathrm{~b}$ & 3.47 & $\mathrm{a}$ & 1.91 & $\mathrm{a}$ & 1.79 & $\mathrm{~b}$ & 33.41 & $\mathrm{a}$ & 33.46 & $\mathrm{a}$ \\
\hline Nano-chitosan 100 ppm & 3. 87 & $\mathrm{a}$ & 3.16 & bc & 1.92 & $\mathrm{a}$ & 1.91 & $\mathrm{a}$ & 33.27 & $\mathrm{a}$ & 33.73 & $\mathrm{a}$ \\
\hline Nano-chitosan 150 ppm & 3.37 & $\mathrm{~b}$ & 3.43 & $\mathrm{a}$ & 1.78 & bc & 1.65 & $\mathrm{c}$ & 31.00 & $\mathrm{c}$ & 31.14 & $\mathrm{c}$ \\
\hline Nano K silicate 0.4 g/L & 2.96 & $\mathrm{~d}$ & 2.99 & $\mathrm{c}$ & 1.82 & $\mathrm{~b}$ & 1. 84 & $\mathrm{~b}$ & 32.38 & $\mathrm{~b}$ & 31.69 & $\mathrm{bc}$ \\
\hline Nano K silicate $0.6 \mathrm{~g} / \mathrm{L}$ & 3.45 & $\mathrm{~b}$ & 3.29 & $a b$ & 1.81 & $\mathrm{~b}$ & 1.91 & $\mathrm{a}$ & 32.38 & $\mathrm{~b}$ & 32.07 & $\mathrm{~b}$ \\
\hline Nano K silicate 0.8 g/L & 3.14 & $\mathrm{c}$ & 3.10 & $\mathrm{c}$ & 1.92 & $\mathrm{a}$ & 1.92 & $\mathrm{a}$ & 33.07 & $a b$ & 32.25 & $\mathrm{~b}$ \\
\hline
\end{tabular}

*Values within a column with similar letter (s) were not significantly different based on the least significant difference at $0.05 \%$.

\section{DISCUSSION}

The good effect of foliar spraying with Nanochitosan and Nano-potassium silicate compared to un- spraying control on flowering, malformation, yield and fruits quality characteristics of the Ewais mango cultivar have been explained by a number of researchers (Anusuya and Sathiyabama, 2016; Zagzog et al., 2017; Laane, 2018; Zahedi and Teixeira da Silva, 2020).

Where Zahedi and Teixeira da Silva (2020) indicated that, application of NFs such chitosan on several fruit trees such as almond, grapes, pomegranate and mangoes had good results. That has a positive direct effect on the growth, the final products and the quality of this fruits. The addition of Nano-chitosan at $5 \mathrm{~mL} \mathrm{~L}^{-1}$ to mango trees improved number of fruit per tree by $35.28 \%$ more than the untreated trees and increased resistance to malformation by $38-40 \%$ more than the non-NF treatment addition to enhanced fruits physical and chemical properties (Zagzog et al., 2017).
The good effect of Nano-chitosan can be attributed to its ability to influence of activity of protease inhibitors, glucanases, and peroxidase, enzymes which promote metabolic processes and growth (Anusuya and Sathiyabama, 2016). Also to the improvement in leaf content of potassium, zinc and chlorophyll as a result of using nanoparticles of chitosan in comparison with untreated trees. Minh and Anh (2013) confirmed this when he mentioned that spraying Nano-chitosan worked on improve leaf chlorophyll about 30-50\%, enhance nutrient uptake $(10-27 \% \mathrm{~N}, 17-30 \% \mathrm{P}, 30-45 \% \mathrm{~K})$ and increase photosynthesis rate about $30 \%$.

As for potassium Nano-silicate which contains Nano-silicon in addition to the Nano-potassium part, the foliar sprays of Nano-silica show a tendency to increase growth and production and reduce biotic stress (Laane, 2018). Furthermore, sprayed mangoes trees with Nano-silica showed the highest leaf chlorophyll and caroteniods pigments plus the highest average leaf area (Elawie et al., 2018). Where Si nanoparticles have physiological properties that allow them to enter plants and influence on metabolic 
activities of plants. In addition to the nature porous of $\mathrm{Si}$ nanoparticles, they are good candidates because they are suitable for various particles that may aid in agriculture (Rastogi, 2019).

However the use of NFs such as N, P, K and $\mathrm{Mg}$ significantly improves the vegetative and productive traits of fruit trees (Zahedi and Teixeira da Silva, 2020). Therefore, the positive effect of using Nano-potassium silicate may was due to its containment nanoparticles of $\mathrm{K}$. Whereas, foliar application of Nano-K increased the number of leaves and length of roots and shoots in plants sprayed with Nano-K fertilizer significantly compared to untreated plants. In addition to, the different concentrations of spraying with Nano-K led to a significant increase in the content of chlorophyll, soluble sugars, and proteins in the leaves and roots of wheat plants as compared to the untreated plant (Tavan et al., 2014). This is in addition to the fact that spraying of Nano-K fertilizer contributed to reduce the plants need for soil potassium fertilizer (Jasim et al., 2020).

The improvement in flowering, fruiting, yield, and fruiting characteristics, which were associated with an improvement in leaf content of potassium, zinc and chlorophyll as a result of the use nanoparticles chitosan or potassium silicate compared to untreated trees, this is due to the role of chlorophyll and these elements to improving photosynthesis and their role in improving flowering, fruit set and fruits traits. Whereas zinc has promising effect on plant metabolism. zinc is responsible for producing the natural hormones IAA, activating certain enzymes for chlorophyll biosynthesis, promoting pollen germination and regulating water uptake by plants (Nijjar, 1985). While potassium affects many important processes of crop formation in plants such as water economy, carbohydrate synthesis and transport of imitations (Mengel and Kirkby, 1982). Therefore, the level of nutrients in the leaf such as potassium and zinc showed a positive and significant relationship with the yield and quality of the pear fruits (Dar et al., 2015). Awasthi et al. (1998) found a direct relationship between leaf nutrients with apple yield and quality. Whereas the concentration of nutrients in the leaves had a great impact on the growth of fruits, the yield and the quality of the fruits.

\section{REFERENCE}

AOAC (1990). Official Methods of Analysis. Association of Official Analytical Chemists, The Association: Arlington, VA, Vol. II, 15th ed. Sec.985.29.
Abdel-Aziz HMM, Hasaneen MNA, Omer AM (2016). Nano chitosan-NPK fertilizer enhances the growth and productivity of wheat plants grown in sandy soil. Span. J. Agric. Res. 14(1).

Agnihotri SA, Mallikarjuna NN, Aminabhavi TM (2004). Recent advances on chitosan based micro- and nanoparticles in drug delivery. Journal of Controlled Release, 100, 5-28.

Anusuya S, Sathiyabama M (2016). Effect of chitosan on growth, yield and curcumin content in turmeric under field condition. Biocat Agric Biotechnol 6:102-106.

Awasthi RP, Bhutani VP, Sharma JC, Kaith NS (1998). Mineral nutrient status of apple orchards of Shimla district of Himachal Pradesh. Indian J. Horti., 55, 314-322.

Chapman HD, Pratt PF (1961). Methods of Analysis for soil, Plant and Waters. University of California, Division of Agriculture Science.

Choudhary RC, Kumaraswamy RV, Kumari S, Sharma SS, Pal A, Raliya R, Biswas P, Saharan V (2017a). Cu-chitosan nanoparticle boosts defense responses and plant growth in maize (Zea mays L.) Sci. Rep. 7: 9754.

Choudhary RC, Kumaraswamy RV, Kumari S, Sharma SS, Pal A, Raliya R, Biswas P, Saharan V (2017b). Synthesis, characterization, and application of chitosan nanomaterials loaded with zinc and copper for plant growth and protection. pp. 227-247.

Dar MA, Wani JA, Raina SK, Bhat MY, Malik MA (2015). Relationship of leaf nutrient content with fruit yield and quality of pear. J. of Environmental Biology, 36(3), 649.

Du J, Gemma H, Iwahori S (1997). Effects of chitosan coating on the storage of peach, Japanese pear and kiwifruit. J. Jpn. Soc. Hort. Sci. 66, 15_22.

Duncan DB (1955). Multiple range and multiple F. Tests biometrics, 11: $1-24$.

Elawie T, Zagzog O, Gad M, Eisa R (2018). Effect of some nano particle materials on leaf area, photo synthetic pigments and minerals content of mango trees. J. of Productivity and Development, 23(3), 535554.

Elsheshetawy HE, Mossad A, Elhelew WK, Farina V (2016). Comparative study on the quality characteristics of some Egyptian mango cultivars used for food processing. Annals of Agric. Sciences, 61: 49-56.

EMALR Egyptian Ministry of Agriculture and Land Reclamation (2004). Mango; cultivation and production. CAAE, ARC, Egypt. Bulletin No. 857.

Gad MM, Ibrahim MM (2018). Effect of IBA and some natural extracts on rooting and vegetative 
growth of Picual olive sucker and shoot cuttings. Current Science International, 7 (2): 191-203.

Ghormade V, Deshpande MV, Paknikar KM (2011). Perspectives for nano-biotechnology enabled protection and nutrition of plants. Biotechnol. Adv. 29: 792-803.

Jasim AH, Sura HR, Hanaa HM (2020). Effect of skip irrigation and nano potassium treatments on maize yield. J. of Eco-Environmental Consultants, 26(3), 10-15.

Kashyap PL, Xiang X, Heiden P (2015). Chitosan nanoparticle-based delivery systems for sustainable agriculture. Int. J. Biol. Macromol. 77: 36-51.

Kikuchi R (1999). Application of coal ash to environmental improvement: transformation into zeolite, potassium fertilizer, and FGD absorbent. Resources. Conservation and Recycling. 27(4) 333346.

Kumaraswamy RV, Kumari S, Choudhary RC, Pal A, Raliya R, Biswas P, Saharan V (2018). Engineered chitosan based nanomaterials: Bioactivities,mechanisms and perspectives in plant protection and growth. Int. J. Biol. Macromol. 113: 494-506.

Laane HM (2018). The effects of foliar sprays with different silicon compounds. Plants 7: 45.

Luyckx M, Hausman JF, Lutts S, Guerriero G (2017). Silicon and plants: current knowledge and technological perspectives. Frontiers in Plant Science, 8,411 .

Ma JF (2004). Role of silicon in enhancing the resistance of plants to biotic and abiotic stresses. Soil Sci Plant Nutr 50:11-18.

Malerba M, Cerana R (2016). Chitosan effects on plant systems. International J. of Molecular Sciences, 17, 996.

Mengel K, Kirkby EL (1982). Principles of Plant Nutrition IPI, Switzerland p. 427- 453.

Minh HD, Anh DN (2013). Study on chitosan nanoparticles on biophysical characteristics and growth of Robusta coffee in green house. Biocatalysis and Agricultural Biotechnology, 2(4), 289-294.

Naderi MR, Danesh-Shahraki A (2013). Nano fertilizers and their roles in sustainable agriculture. Int. J. Agric. Crop Sci., 5(19):2229-2232.

Nair R, Varghese SH, Nair BG, Maekawa T, Yoshida Y, Kumar DS (2010). Nanoparticulate material delivery to plants. Plant Sci. 179: 154-163.

Nido PJ, Migo V, Maguyon-Detras MC, Alfafara C (2019). Process Optimization Potassium Nanofertilizer Production via Ionotropic Pre-gelation using AlginateChitosan Carrier. In MATEC Web of Conferences (Vol. 268, p. 05001). EDP Sciences.
Nijjar GS (1985). Nutrition of fruit trees. Mrs. Usha. Raj Kumar Kalayan, New Delhi, pp:70-119.

O'Farrell N, Houlton A, Horrocks BR (2006). Silicon nanoparticles: applications in cell biology and medicine. Int J Nanomed, 1(4):451-472

Rastogi A, Tripathi DK, Yadav S, Chauhan DK, Živčák M, Ghorbanpour M, Brestic M (2019). Application of silicon nanoparticles in agriculture. 3 Biotech, 9(3), 1-11.

Riad M (1997). Mango production in Egypt. Acta horticulturae, 1, 1-6.

Roduner E (2006). Size matters: why nanomaterials are different. Chem Soc Rev 35(7):583-592.

Saharan V, Sharma G, Yadav M, Choudhary MK, Sharma SS, Pal A, Raliya R, Biswas P (2015). Synthesis and in vitro antifungal efficacy of $\mathrm{Cu}$ chitosan nanoparticles against pathogenic fungi of tomato. Int. J. Biol. Macromol. 75: 346-353.

Saharan V, Kumaraswamy RV, Choudhary RC, Kumari S, Pal A, Raliya R, Biswas P (2016). Cuchitosan nanoparticle mediated sustainable approach to enhance seedling growth in maize by mobilizing reserved food. J. Agric. Food Chem. 64(31): 61486155.

Savvas D, Ntatsi G (2015). Biostimulant activity of silicon in horticulture. Scientia Horticulturae, 196, 6681.

Snedecor GW, Cochran WG (1980). Statistical Methods. Sixth Edition Iowa State Unit. Press, Ames, Iowa, U. S. pp 1207 - 1285.

Steel RG, Torrie JH (1980). Principles and procedures of statistics. Me-Graw Hill Book Co. Inc., NY, USA, 633.

Tavan T, Niakan M, Norinia A (2014). Effect of nano-potassium fertilizer on growth factors, photosynthetic system and protein content in wheat (Triticum aestivum L. Cv. N8019).

Thornton PK (2010). Livestock production: Recent trends, future prospects. Phil. Trans. R. Soc. B 365(1554): 2853-2867.

Wettestein DV (1957). Chlorophyll, lethal und der Submikroscopische Formwechsel der plastiden. Expt . Cell-Research, 12: 427-433.

Wu L, Liu M (2007). Slow-release potassium silicate fertilizer with the function of superabsorbent and water retention Ind Eng Chem Res 46(20) 6494-6500. Yao Y, Yoneyama T, Hayashi H (2003). Potassium uptake by Chinese cabbage (Brassica pekinensis Rupy) from fused potassium silicate, a slow-releasing fertilizer. Plant Soil 249(2) 279-286.

Zagzog OA, Gad MM, Hafez NK (2017). Effect of nano-chitosan on vegetative growth, fruiting and 


\section{M.M. Gad et al., 2021}

resistance of malformation of mango. Trends Hortic. yield of fruit crops. J. of the Science of Food and Res, 6, 673-681.

Agriculture, 100(1), 25-31.

Zahedi SM, Karimi M, Teixeira da Silva JA (2020).

The use of nanotechnology to increase quality and

\section{الملخص العزبي}

تحسين المحصول والمواصفات الثمرية للمانجو صنف عويس بالرش بالنانو شيتوزان والنانوبوتاسيوم سيليكات

$$
\begin{aligned}
& \text { عحمد ممتاز جاد'، عحم عبد العزيز عبد المحسن ، أسامة أحمد زقزوق } \\
& \text { ' ق قسم البساتين، كلية الزراعة، جامعة الزقازيق، الثرقية، مصر }
\end{aligned}
$$

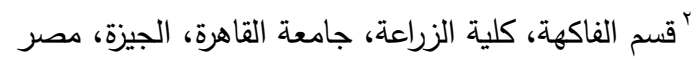

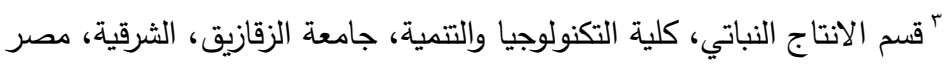

أجريت هذه الدراسة لتحسين الإزهار، الانتاجية وجودة ثمار المانجو صنف عويس وذلك بالرش بالنانو شيتوزان والنانو بوتاسيوم سليكات. اشتملت

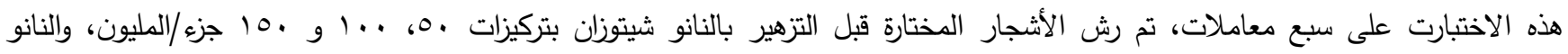

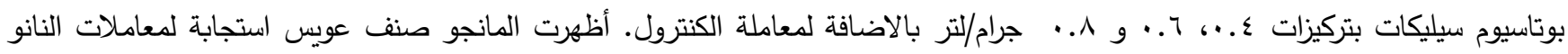
تحت ظروف هذه التجربة سواء للثيتوزان أو سليكات البوتاسيوم، بالمقارنة بالأثجار الغير معاملة والتى أعطت أقل نتائج فى المواصفات المرتبطة باتهات

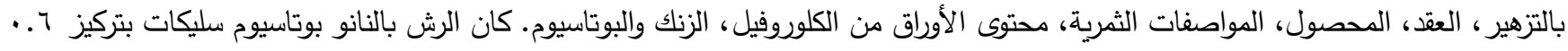

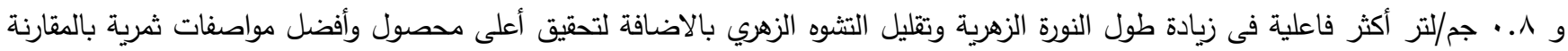

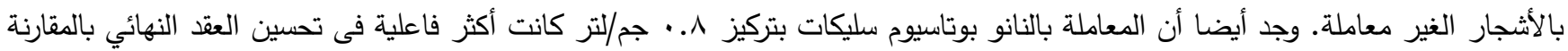

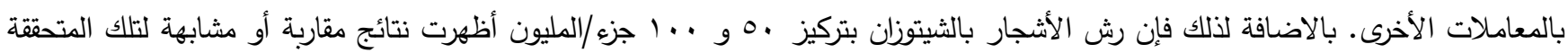

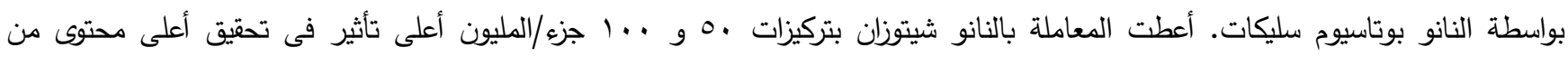
الكلوروفيل فى الأوراق، الزنك و البوتاسيوم.

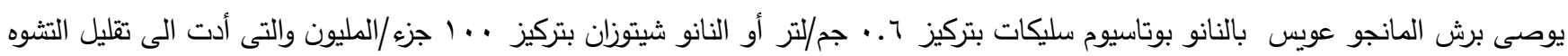
الزهري وحققت أعلى محصول وأفضل صفات ثمرية. 